\title{
Biomechanical analysis of topspin techniques in table tennis games
}

\author{
Aulia Gusdernawati ${ }^{1 *}$, Widiyanto ${ }^{2}$, Ahmad Nasrulloh ${ }^{3}$ \\ ${ }^{1}$ Ilmu Keolahragaan, Program Pascasarjana, Universitas Negeri Yogyakarta, Jl. Colombo No. 1, Karangmalang, \\ Depok, Sleman, Daerah Istimewa Yogyakarta, Indonesia. \\ ${ }^{2,3}$ Ilmu Keolahragaan, Universitas Negeri Yogyakarta, Jl. Colombo No. 1, Karangmalang, Depok, Sleman, Daerah \\ Istimewa Yogyakarta, Indonesia. \\ Corresponding author: auliagusdernawati.2020@student.uny.ac.id
}

\begin{abstract}
Motion analysis in sports can help athletes and coaches as material for evaluating movement in improving movement and improving athlete performance with a predetermined training program. The purpose of this study was to analyze the motion of the topspin technique in table tennis. This research is a qualitative research by describing the results of the video analysis of the topspin technique movement which is accessed from youtube, then using the Kinovea application instrument. The subjects in this study were the top ranked players, which consisted of five of the best male athletes at the world level in the table tennis game. Based on the analysis data above, it was found that the average bending of the elbow at the ready position was $92.8^{0}$, the swing position before hitting the ball was $142.4^{0}$, when hitting the ball was $117.8^{0}$, and after hitting the ball was $73.4^{\circ}$. The results of the average elbow distance from the center point when the ready position is $68.728 \mathrm{~cm}$, when the swing position before hitting the ball is $23.532 \mathrm{~cm}$, when hitting the ball with a distance of $50.88 \mathrm{~cm}$ and during further motion 150.768 $\mathrm{cm}$. The results of the analysis of the inclination angle of the body when the ready position is $161.6^{0}$, when swinging the hand $152.6^{\circ}$, when hitting the ball 150.6 , and for further motion with a body inclination of $166^{\circ}$. The results of the analysis of the bending of the right leg when the position is $149.8^{0}$, the position of swinging the right leg $125.4^{\circ}$, and when the ball hits it forms an angle of $125.6^{\circ}$ and when it continues to move $42.6^{\circ}$. The average results of the analysis of the left leg bending angle when the ready position is $151.2^{\circ}$, the swinging position with the left leg bending is $126.2^{\circ}$, in the position of the ball hitting an angle of $130.4^{0}$, and accompanied by a follow-up motion to form the left foot angle of $146^{\circ}$. The average foot distance when hitting the topspin, in the ready position is $186 \mathrm{~cm}$, during the backswing the foot distance is $196.638 \mathrm{~cm}$, and when hitting the ball is $198.81 \mathrm{~cm}$, and accompanied by a follow-up motion of $195.886 \mathrm{~cm}$. Biomechanical analysis of the topspin technique from several stages starting from the ready position to the advanced motion carried out by each athlete according to their respective body anatomy and following the position when hitting the ball.
\end{abstract}

Keywords: Biomechanics, Analysis, Topspin Techniques

\section{Analisis biomekanika teknik topspin pada permainan tenis meja}

\begin{abstract}
Abstrak
Analisis gerak pada olahraga dapat membantu atlet dan pelatih sebagai bahan evaluasi gerakan dalam memperbaiki gerakan dan meningkatkan performa atlet dengan program latihan yang telah ditentukan. Tujuan penelitian ini ialah menganalisis gerak teknik topspin dalam permainan tenis meja. Penelitian ini merupakan penelitian kualitatif dengan mendeskripsikan hasil analisis video gerakan teknik topspin yang diakses dari youtube, kemudian menggunakan instrumen aplikasi Kinovea. Subyek dalam penelitian ini men top ranked players yang berjumlah lima orang atlet putra terbaik ditingkat dunia pada permainan tenis meja. Berdasarkan dari data analisis diatas ditemukan nilai rerata tekukan siku pada saat posisi siap $92,8^{0}$, posisi ayunan sebelum memukul bola $142,4^{0}$, saat memukul bola $117,8^{0}$, dan sesudah memukul bola sebesar $73,4^{0}$. Hasil rerata jarak siku dari titik pusat saat posisi siap $68,728 \mathrm{~cm}$, saat posisi ayunan sebelum memukul bola $23,532 \mathrm{~cm}$, saat memukul bola dengan jarak 50,88 cm dan saat gerak lanjutan $150,768 \mathrm{~cm}$. Hasil analisis sudut kecondongan tubuh saat posisi siap $161,6^{0}$, saat mengayunkan tangan $152,6^{0}$, saat memukul bola $150,6^{\circ}$, dan untuk gerak lanjutan dengan kecondongan


tubuh $166^{\circ}$. Hasil analisis tekukan kaki kanan saat posisi $149,8^{0}$, posisi mengayunkan kaki kanan $125,4^{0}$, dan saat perkenaan bola membentuk sudut $125,6^{0}$ dan saat gerak lanjutan $42,6^{0}$. Hasil rerata analisis sudut tekukan kaki kiri saat posisi siap $151,2^{\circ}$, posisi mengayungkan tangan dengan tekukan kaki kiri $126,2^{0}$, pada posisis perkenaan bola membentuk sudut $130,4^{0}$, serta diiringi dengan gerak lanjutan membentuk sudut kaki kiri $146^{\circ}$. Hasil rerata jarak kaki saat melakukan pukulan topspin, pada posisi siap $186 \mathrm{~cm}$, saat backswing jarak kaki 196,638 cm, dan saat perkenaan bola 198,81 cm, serta di iringi gerak lanjutan 195,886 cm. Analisis biomekanik teknik topspin dari beberapa tahapan dimulai dari posisi siap hingga gerak lanjutan yang dilakukan masing-masing atlet sesuai anatomi tubuh masingmasing serta mengikuti posisi saat perkenaan bola.

Kata kunci : Biomekanika, Analisis, Teknik Topspin

\section{PENDAHULUAN}

Olahraga sudah menjadi kebutuhan global untuk skala dan intensitas dalam meningkatkan kuliatas kehidupan ilmiah harus menjadi faktor dalam pertumbuhan kehidupan olahraga yang berkualitas. Olahraga juga sebagai bentuk aktivitas yang mengkaitkan kemampuan fisik, jasmani, dan juga rohani seseorang (Sumaryanto 2015). Tenis meja menjadi salah satu olahraga yang popular di dunia hal ini dibuktikan data yaitu lebih dari 300 juta pemain tenis meja yang aktif (Anon n.d.). Olahraga ini merupakan olahraga indoor yang dimainkan dengan memantulkan bola diatas permukaan meja, melewat net dan memukulnya menggunakan blade yang dilapisi oleh rubber. Tenis meja adalah satu olahraga yang membutuhkan kelincahan supaya atlet mampu melakukan gerakan dan kekuatan yang maksimal (Nikolić, Furjan-Mandić, and Kondrič 2014), oleh karena itu untuk meningkatan prestasi atlet teknik dasar dalam permainan menjadi modal utama yang harus dikuasai seorang atlet tenis meja. Pada olahraga ini ada beberapa jenis teknik pukulan yang dapat membantu untuk mengembalikan bola ke area lawan untuk mendapatkan poin (Ismi, Hadi, and Nurdin 2020).

Tenis meja telah mengalami perkembangan yang sangat pesat, perubahan yang terjadi pada tenis meja di tahun 2014 dengan munculnya bola plastik sebagai pengganti bola celluloid, tentunya atlet perlu beradaptasi dengan bola baru. Sangat penting untuk membangun sistem latihan yang baru untuk menguasai kemenangan dalam permainan tenis meja, dan menerapkan metode dan ukuran latihan ilmiah ke dalam pelatihan harian. Oleh karena itu, seorang atlet dapat terus memperbarui teknik dalam permainannya (Chiwen et al. 2019). Teknik topspin sering digunakan oleh beberapa atlet tenis meja sebagai pukulan serangan, dimana pukulan topspin ialah satu gerakan yang paling kuat karena tubuh tidak menghalangi saat melakukan gerakannya. Selain itu teknik topspin ini sebagai pukulan menyerang tentu saja memahami karakteristik biomekanik dari teknik topspin sangat diperlukan untuk atlet dan pelatih. Pada pukulan ini otot yang digunakan biasanya lebih maksimal dari pada pukulan lainnya, dan juga kecepatan blade pada saat bersentuhan dengan bola mencapai $20 \mathrm{~m} / \mathrm{s}$, setelah perkenaan bet bola mencapai kecepatan hingga $45 \mathrm{~m} / \mathrm{s}$, berputar hingga 140 putaran per detik (Bańkosz and Winiarski 2016; lino and Kojima 2016; Padulo et al. 2016).

Meningkatnya popularitas dan persaingan sengit dalam tenis meja telah mengakibatkan munculnya metode analisis untuk memahami taktik permainan dengan lebih baik dan meningkatkan kinerja tim. Dalam pendekatan ilmiah yang seiring dengan kemajuan teknologi sangat berkembang pesat, metode dalam menganalisis gerak dengan menggunakan prinsip biomekanika yang berkorelasi dengan gerakan tubuh dan gerakan yang dilakukan supaya lebih efektif dan efesien (Irmawati, Kresnapati, and Isna 2020). Dalam menganalisis suatu gerakan tentunya menggunakan teknik berbasis video yang memberikan umpan balik ekstrinsik (Pueo 2016), kemudian dianalisis kinetika dan kinematika yang dijabarkan berupa pengukuran atau kecepatan suatu gerakan (Sanders et al. 2006).

Menganalisis suatu gerakan tubuh yang dilakukan dengan menghitung pergerakan kinematikanya tanpa mempertimbangkan faktor gaya apa yang menyebabkan terjadinya 
gerakan tersebut, informasi ini dapat dinyatakan dengan proses yang lebih lanjut dengan cara menampilkan model otot kerangka yang kompleks (Pueo and Jimenez-Olmedo 2017). Ketika atlet melakukan suatu gerakan dengan kecepatan yang tinggi tentunya sangat sulit jika menganalisis hanya menggunakan indera penglihatan, karena pengamatan hanya dalam dilihat dan diamati secara sepintas, sehingga dibutuhkan bantuan analisis menggunakan teknologi yang dapat berupa software atau aplikasi (Suwadji, Ade 2014). Analisis gerak pada olahraga dapat membantu atlet dan pelatih sebagai bahan evaluasi gerakan dalam memperbaiki gerakan yang salah dan meningkatkan performa atlet dengan perencanaan latihan yang telah ditentukan (Southgate, Prinold, and Weinert-Aplin 2016).

Berdasarkan permasalahan yang telah dipaparkan mengenai unsur biomekanika dalam permainan tenis meja pada teknik topspin, penulis bermaksud untuk mengetahui analisis teknik topspin oleh atlet dunia yang dimulai dari posisi saat siap hingga gerak lanjutan, diharapkan hal ini bisa membantu atlit dan pelatih dalam mengevaluasi serta meksimalkan gerakan, meningkatkan performa, dan dapat meminimalisir terjadinya cidera pada atlet. Penelitian ini untuk memperolehan data analisis dan pemahaman yang lebih baik dalam permainan tenis meja khususnya pada teknik topspin. Sebuah analisis dalam suatu gerakan dapat mendukung narasi permainan, eksplorasi statisik, dan dapat mendeteksi pola gerakan teknik topspin dalam tenis meja.

\section{METODE}

Jenis penelitian ini adalah penelitian kualitatif. Dalam penelitian ini peneliti menganalisis teknik topspin tenis meja dengan rekaman video yang meliputi sudut tekukan siku, jarak siku dari titik pusat, sudut kecondongan tubuh, sudut tekukan kaki kanan, sudut tekukan kaki kiri, dan jarak bukaan kaki pada saat posisi siap, mengayunkan tangan sebelum perkenaaan bola, posisi saat perkenanaan bola, dan gerak lanjutan. Item yang dianalisis diperoleh atas pertimbangan dari langkah-langkah untuk melakukan gerakan topspin yang diamati dari buku (Kertamanah 2015) Penelitian ini dilaksanakan pada tanggal 3 - 30 April 2021.

Teknik penarikan sampel dalam penelitian ini menggunakan teknik sampling sistematis yang mana penarikan sampel berdasarkan nomor urut dari jumlah populasi (Sugiyono 2019). Populasi dalam penelitian ini ialah atlet tenis meja putra dengan sampel penelitian berdasarkan men top ranked players yang berjumlah lima orang atlet putra terbaik ditingkat dunia pada permainan tenis meja, urutan tersebut didapatkan dari urutan peringkat 1 sampai 5 yang diunggah pada webiste world table tenis yang diakses pada 20 april 2021. Pada peringkat 1 Fan Zhendong, peringkat $2 \mathrm{Xu}$ Xin, Peringkat $3 \mathrm{MA}$ Long, Peringkat 4 Tomokazu Harimoto, peringkat 5 LIN Gaoyuan.

Pada penelitian ini menganalisis teknik topspin dalam permainan tenis meja, dengan menggunakan instrumen utama yang dibutuhkan meliputi aplikasi Kinovea, video teknik topsin berisi jenis penelitian yang diakses dari youtube. Data yang dikumpulkan dalam pelaksanaan penelitian ini adalah data penampilan teknik topspin tenis meja yang diperoleh dari subjek penelitian, sehingga akan diketahui penampilan gerak teknik topspin yang maksimal. Data yang telah diunduh dijadikan satu folder, kemudian menganalisis teknik topspin dengan menggunakn aplikasi Kinovea. Setelah menemukan hasil sudut tekukan siku, jarak siku dari titik pusat, sudut kecondongan tubuh, sudut tekukan kaki kanan, sudut tekukan kaki kiri, dan jarak bukaan kaki, selanjutnya peneliti mencari nilai rata-rata setiap aspek yang diteliti.

\section{HASIL DAN PEMBAHASAN}

Hasil deskriptif penelitian analisis biomekanika teknik topspin pada permainan tenis meja hasil analisis oleh men top five ranked players yang disajikan pada tabel 1 sebagai berikut: 
MEDIKORA, Vol. 20 No. 2 Oktober - 128

Aulia Gusdernawati, Widiyanto, Ahmad Nasrulloh

Tabel 1. Hasil analisis teknik topspin

\begin{tabular}{|c|c|c|c|c|c|}
\hline No. & Nama & $\begin{array}{l}\text { Posisi } \\
\text { Siap }\end{array}$ & $\begin{array}{l}\text { Posisi ayunan } \\
\text { sebelum } \\
\text { Memukul }\end{array}$ & $\begin{array}{l}\text { Posisi Saat } \\
\text { Memukul } \\
\text { Bola }\end{array}$ & $\begin{array}{l}\text { Posisi } \\
\text { Sesudah } \\
\text { Memukul } \\
\text { Bola }\end{array}$ \\
\hline \multirow[t]{6}{*}{1.} & Sudut tekukan siku & & & & \\
\hline & FAN Zhendong & $91^{\circ}$ & $160^{\circ}$ & $114^{\circ}$ & $73^{\circ}$ \\
\hline & XU Xin & $70^{\circ}$ & $128^{\circ}$ & $131^{\circ}$ & $86^{\circ}$ \\
\hline & MA Long & $109^{\circ}$ & $183^{\circ}$ & $108^{\circ}$ & $64^{\circ}$ \\
\hline & Tomokazu HARIMOTO & $98^{\circ}$ & $104^{\circ}$ & $128^{\circ}$ & $64^{\circ}$ \\
\hline & LIN Gaoyuan & $96^{\circ}$ & $137^{\circ}$ & $108^{\circ}$ & $80^{\circ}$ \\
\hline \multirow[t]{6}{*}{2.} & Jarak siku dari titik pusat & & & & \\
\hline & FAN Zhendong & $96,71 \mathrm{~cm}$ & $25,34 \mathrm{~cm}$ & $57,73 \mathrm{~cm}$ & $147,58 \mathrm{~cm}$ \\
\hline & XU Xin & $100 \mathrm{~cm}$ & $21,57 \mathrm{~cm}$ & $82,80 \mathrm{~cm}$ & $229,56 \mathrm{~cm}$ \\
\hline & MA Long & $51,73 \mathrm{~cm}$ & $21.09 \mathrm{~cm}$ & $29,98 \mathrm{~cm}$ & $90,18 \mathrm{~cm}$ \\
\hline & Tomokazu HARIMOTO & $28,55 \mathrm{~cm}$ & $20,68 \mathrm{~cm}$ & $55,41 \mathrm{~cm}$ & $123,40 \mathrm{~cm}$ \\
\hline & LIN Gaoyuan & $66,65 \mathrm{~cm}$ & $28,98 \mathrm{~cm}$ & $28,48 \mathrm{~cm}$ & $163,12 \mathrm{~cm}$ \\
\hline \multirow[t]{6}{*}{3.} & Sudut kecondongan tubuh & & & & \\
\hline & FAN Zhendong & $158^{\circ}$ & $147^{\circ}$ & $150^{\circ}$ & $162^{\circ}$ \\
\hline & XU Xin & $168^{\circ}$ & $151^{\circ}$ & $154^{\circ}$ & $166^{\circ}$ \\
\hline & MA Long & $160^{\circ}$ & $144^{\circ}$ & $150^{\circ}$ & $172^{\circ}$ \\
\hline & Tomokazu HARIMOTO & $158^{\circ}$ & $164^{\circ}$ & $153^{\circ}$ & $160^{\circ}$ \\
\hline & LIN Gaoyuan & $164^{\circ}$ & $157^{\circ}$ & $146^{\circ}$ & $170^{\circ}$ \\
\hline \multirow[t]{6}{*}{4.} & Sudut tekukan kaki kanan & & & & \\
\hline & FAN Zhendong & $143^{\circ}$ & $126^{\circ}$ & $120^{\circ}$ & $122^{\circ}$ \\
\hline & XU Xin & $142^{\circ}$ & $141^{\circ}$ & $143^{\circ}$ & $153^{\circ}$ \\
\hline & MA Long & $143^{\circ}$ & $119^{\circ}$ & $112^{\circ}$ & $129^{\circ}$ \\
\hline & Tomokazu HARIMOTO & $159^{\circ}$ & $124^{\circ}$ & $120^{\circ}$ & $140^{\circ}$ \\
\hline & LIN Gaoyuan & $162^{\circ}$ & $117^{\circ}$ & $133^{\circ}$ & $169^{\circ}$ \\
\hline \multirow[t]{6}{*}{5.} & Sudut tekukan kaki kiri & & & & \\
\hline & FAN Zhendong & $153^{\circ}$ & $118^{\circ}$ & $121^{\circ}$ & $151^{\circ}$ \\
\hline & XU Xin & $132^{\circ}$ & $155^{\circ}$ & $110^{\circ}$ & $119^{\circ}$ \\
\hline & MA Long & $166^{\circ}$ & $114^{\circ}$ & $125^{\circ}$ & $156^{\circ}$ \\
\hline & Tomokazu HARIMOTO & $154^{\circ}$ & $121^{\circ}$ & $171^{\circ}$ & $170^{\circ}$ \\
\hline & LIN Gaoyuan & $151^{\circ}$ & $123^{\circ}$ & $125^{\circ}$ & $134^{\circ}$ \\
\hline \multirow[t]{6}{*}{6.} & Jarak bukaan kaki & & & & \\
\hline & FAN Zhendong & $171,36 \mathrm{~cm}$ & $171,66 \mathrm{~cm}$ & $168,52 \mathrm{~cm}$ & $168,52 \mathrm{~cm}$ \\
\hline & XU Xin & $257,21 \mathrm{~cm}$ & $239,24 \mathrm{~cm}$ & $217,40 \mathrm{~cm}$ & $229,56 \mathrm{~cm}$ \\
\hline & MA Long & $83,77 \mathrm{~cm}$ & $90,86 \mathrm{~cm}$ & $89,91 \mathrm{~cm}$ & $93,60 \mathrm{~cm}$ \\
\hline & Tomokazu HARIMOTO & $137,83 \mathrm{~cm}$ & $153,94 \mathrm{~cm}$ & $169,07 \mathrm{~cm}$ & $144,83 \mathrm{~cm}$ \\
\hline & LIN Gaoyuan & $279,86 \mathrm{~cm}$ & $327,49 \mathrm{~cm}$ & $349,15 \mathrm{~cm}$ & $342,92 \mathrm{~cm}$ \\
\hline
\end{tabular}

Data hasil penelitian ini diambil sesuai dengan rumusan dan tujuan penelitian menganalisis gerak teknik topspin tenis meja. Beberapa hasil pengukuran yang disajikan dalam penelitian untuk bahan analisis diperoleh hasil rerata dari teknik topspin men top five ranked players setiap posisi siap, posisi ayunan, posisi saat perkenaan bola, hingga gerak lanjutan disajikan pada tabel 2 sebagi berikut:

Tabel 2. Hasil analisis rerata teknik toppsin

\begin{tabular}{llllll}
\hline No. & Ananlisis Pengukuran & Posisi Siap & $\begin{array}{l}\text { Posisi ayunan } \\
\text { sebelum } \\
\text { Memukul }\end{array}$ & $\begin{array}{l}\text { Posisi Saat } \\
\text { Memukul } \\
\text { Bola }\end{array}$ & $\begin{array}{l}\text { Posisi Sesudah } \\
\text { Memukul Bola }\end{array}$ \\
\hline 1. & Sudut tekukan siku & $92.8^{\circ}$ & $142.4^{\circ}$ & $117.8^{\circ}$ & $73.4^{\circ}$
\end{tabular}


MEDIKORA, Vol. 20 No. 2 Oktober - 129

Aulia Gusdernawati, Widiyanto, Ahmad Nasrulloh

2. Jarak siku dari titik pusat

3. Sudut kecondongan tubuh

$68.728 \mathrm{~cm}$

$161.6^{\circ}$

$149.8^{\circ}$

$151.2^{\circ}$

$186 \mathrm{~cm}$

$$
23.532 \mathrm{~cm}
$$

$152.6^{\circ}$

$125.4^{\circ}$

$126.2^{\circ}$

$196.638 \mathrm{~cm}$
$50.88 \mathrm{~cm}$

$150.6^{\circ}$

$125.6^{\circ}$

$130.4^{\circ}$

$198.81 \mathrm{~cm}$
$150.768 \mathrm{~cm}$

$166^{\circ}$

$142.6^{\circ}$

$146^{\circ}$

$195.886 \mathrm{~cm}$

Berdasarkan data analisis diatas ditemukan nilai rerata tekukan siku pada saat posisi siap sebesar $92,8^{\circ}$, kemudian pada saat posisi ayunan sebelum memukul bola dengan sudut tekukan siku $142,4^{0}$, selanjutnya sudut tekukan siku saat memukul bola sebesar $117,8^{0}$, lebih lanjut didapatkan sudut tekukan siku sesudah memukul bola sebesar $73,4^{0}$. Hasil rerata jarak siku dari titik pusat saat posisi siap $68,728 \mathrm{~cm}$, saat posisi ayunan sebelum memukul bola 23,532 cm, untuk posisi saat memukul bola dengan jarak $50,88 \mathrm{~cm}$, dan jarak siku ke pusat saat gerak lanjutan $150,768 \mathrm{~cm}$. Selanjtunya hasil analisis sudut kecondongan tubuh saat posisi siap $161,6^{0}$, saat mengayunkan tangan $152,6^{\circ}$, kemudian kecondongan tubuh saat memukul bola $150,6^{\circ}$, dan untuk gerak lanjutan dengan kecondongan tubuh $166^{\circ}$. Untuk hasil analisis tekukan kaki kanan saat posisi siap $149,8^{\circ}$, posisi megayunkantangan $125,4^{0}$, saatperkenaan bola $125,6^{0}$, dan saat melakukan gerak lanjutan $142,6^{\circ}$. Dilanjutkan hasil rerata analisis sudut tekukan kaki kiri saat posisi siap $151,2^{0}$, posisi mengayungkan tangan dengan tekukan kaki kiri $126,2^{0}$, pada saat perkenaan bola membentuk sudut $130,4^{0}$, serta diiringi dengan gerak lanjutan membentuk sudut kaki kiri $146^{\circ}$. Serta menganalisis hasil rerata jarak kaki saat melakukan pukulan topsin pada posisi siap $186 \mathrm{~cm}$, saat backswing jarak kaki 196,638 cm, dan saat perkenaan bola 198,81 $\mathrm{cm}$, serta diringi gerak lanjutan 195,886 cm.

Pada olahraga prestasi untuk meraih puncak prestasi atlet, seorang pelatih harus mampu mencukupi kebutuhan atlet selama program latihan diberikan kepada atlet dalam jangka waktu yang telah ditentukan dengan melakukan evaluasi hasil yang dicapai dengan alat bantu (Saleh and Widiyanto 2019). Mencapai hasil yang maksimal pada olahraga prestasi maka diperlukan program latihan yang dibuat secara terukur dan juga teratur yang ditunjang dari berbagai disiplin ilmu, pengetahuan, dan teknologi. Pada umumnya tiap cabang olahraga ditunjang oleh kondisi fisik yang baik, dalam proses mencapai prestasi latihan fisik seorang atlet didukung oleh teknologi yang menjadi pondasi dasar yang harus dilakukan setiap atlet selain meningkatkan latihan teknik, taktik dan mental. Meningkatnya kualitas teknologi olahraga saat ini menjadi salah satu faktor yang meningkatkan prestasi yang dimanfaatkan untuk latihan yang melalui pendekatan ilmiah.

Perkembangan ilmu pengetahuan dan teknologi atau IPTEK pada olahraga sudah sangat berkembang pesat dan munculnya inovasi-inovasi baru yang menunjang aktivitas olahraga. Teknologi mampu membantu atlet dan pelatih pada olahraga prestasi untuk meningkatkan proses latihan supaya mendapatkan hasil maksimal (Santosa 2016). Selain teknologi, dalam proses latihan hendaknya dilakukan sesuai dengan prinsip-prinsip latihan, (Nasrulloh 2009). Tujuan dan sasaran latihan akan tercapai dengan baik jika latihan dilakukan sesuai dengan prinsip dasar latihan yang benar, (Nasrulloh et al. 2020). Demikian halnya latihan teknik topspin pada tenis meja haris memperhatikan prinsip latihan yang tepat. Untuk mendapatkan hasil yang maksimal tentunya kita perlu mengetahui terlebih dahulu seperti apa gerakan topspin yang benar, dari hasil analisis teknik topspin yang dilakukan oleh men top five ranked players yang telah dibahas sebelumnya. Dapat diketahui gerakan yang dilakukan oleh lima atlet tersebut tidak terlalu adanya perbedaan gerakan yang dilakukan. Hal ini dapat diamati pada tabel 1 hasil analisis teknik topspin, namun pada jarak bukaan kaki dan sudut kecondongan tubuh dilakukan masing-masing atlet sesuai anatomi tubuh masing-masing serta mengikuti posisi saat perkenaan bola. 
Menganalisis satu gerakan saat atlet melakukan pukulan topspin didapatkan hasil sudut tekukan siku saat posisi siap siku membentuk sudut siku-siku, kemudian saat melakukan back swing siku diayunkan dengan membentuk sudut yang lebih luas lagi untuk mendapatkan ayunan yang kuat saat perkenan bola, dan diikuti dengan gerak lanjutan yang membentuk sudut lancip. Kemudian hasil analisis jarak siku dari titik pusat saat posisi siap dan perkenaan bola dengan jarak yang sama, saat posisi back swing jarak siku menjadi lebih dekat dekat titik pusat, dan diikuti dengan gerak lanjutan yang menjadi jarak terjauh siku dari titik pusat. Selanjutnya analisis sudut kecondongan tubuh dalam melakukan gerakan teknik topspin saat posisi back swing dan perkenaan bola di mana sudut tubuh yang paling condong kedepan. Dilanjutkan sudut tekukan kaki kanan dan kaki kiri saat melakukan pukulan topspin kaki kiri berada didepan dan kaki kiri berada sedikit kebelakang dan tumpuan berada pada kaki kiri, namun posisi kaki kanan lebih menekuk dibandingkan kaki kiri begitu juga sebaliknya untuk pemain kidal tumpuan berada pada kaki kanan dan kaki yang lebih menekuk kaki kiri. Untuk jarak bukaan kaki saat mengikuti gerakan yang sebelumnya, jarak bukaan kaki terdekat pada saat posisi siap, kemudian pada saat backswing, perkenaan bola, dan gerak lanjutan jarak bukaan kaki lebih ditambah.

Berdasarkan dari data analisis diatas ditemukan nilai rerata tekukan siku pada saat posisi siap $92,8^{0}$, posisi ayunan sebelum memukul bola $142,4^{0}$, saat memukul bola $117,8^{0}$, dan sesudah memukul bola sebesar $73,4^{0}$. Hasil rerata jarak siku dari titik pusat saat posisi siap $68,728 \mathrm{~cm}$, saat posisi ayunan sebelum memukul bola $23,532 \mathrm{~cm}$, saat memukul bola dengan jarak 50,88 cm dan saat gerak lanjutan 150,768 cm. Hasil analisis sudut kecondongan tubuh saat posisi siap $161,6^{0}$, saat mengayunkan tangan $152,6^{0}$, saat memukul bola $150,6^{0}$, dan untuk gerak lanjutan dengan kecondongan tubuh $166^{\circ}$. Hasil analisis tekukan analisis tekukan kaki kanan saat posisi siap $149,8^{0}$, posisi megayunkantangan $125,4^{0}$, saatperkenaan bola $125,6^{0}$, dan saat melakukan gerak lanjutan $142,6^{\circ}$. Hasil rerata analisis sudut tekukan kaki kiri saat posisi siap $151,2^{0}$, posisi mengayungkan tangan dengan tekukan kaki kiri $126,2^{0}$, pada posisis perkenaan bola membentuk sudut $130,4^{0}$, serta diiringi dengan gerak lanjutan membentuk sudut kaki kiri $146^{\circ}$. Hasil rerata jarak kaki saat melakukan pukulan topspin n pada posisi siap $186^{0}$ $\mathrm{cm}$, saat backswing jarak kaki 196,638 cm, dan saat perkenaan bola 198,81 cm, serta di iringi gerak lanjutan 195,886 cm.

Analisis biomekanik teknik topspin dari beberapa tahapan dalam melakukan gerakan dimulai dari saat posisi siap yang merupakan posisi ideal untuk melakukan teknik topspin dengan posisi kepala menyesuaikan pandangan mata terhadap sasaran bola untuk mendapatkan raihan yang lebih baik. Pada fase mengayunkan tangan dilakukan untuk menarik dan menambah perputaran bola, sebelum perkenaan bola dilakukan dengan sikap agak membungkuk dan mengayunkan blade di ikuti dengan gerakan putaran pinggang atas. Kemudian posisi saat perkenaan bola kekuatan penuh diperoleh perpindahan energi dari badan ke blade. Selanjutnya di ikuti gerak lanjutan untuk persiapan melakukan pukulan selanjutnya.

Teknik topspin yang di analisis sesuai dengan perkembangan tenis meja saat ini dengan menggunakan bola plastik, tentunya tingkat melakukan pukulan menyerang dan kebutuhan lainnya meningkat. Hasil yang di peroleh nilai antarindividu dengan nilai yang berbeda dan telah di temukan nilai rerata setiap posisi dan saat melakukan gerakan, akan tetapi hasil analisis gerakan ini pada saat pemain mengulangi gerakan yang sama bukan berarti atlet tersebut dapat mengulangi gerakan yang sama dengan hasil analisis pula. Hal ini dikarenakan variabilitas dalam tiap gerakan berkarakter fungsional dan kompensasi yang mempengaruhi penyesuaian motorik dari berbagai parameter gerakan untuk menghindari cedera (Bartlett, Wheat, and Robins 2007). Pada saat perkenaan bola, beberapa atlet menunjukkan variabilitas sudut yang tinggi, terutama dalam ekstensi pada sendi pergelangan tangan, perubahan pada satu sendi dikompensasikan dengan perubahan pada sendi lainnya (Bańkosz and Winiarski 2020). Setelah perkenaan bola dengan bet maka diikuti dengan gerak lanjutan untuk memperkuat teknik 
topspin dengan melakukan ayunan kedepan, supaya memberikan gerakan yang stabil antara lengan yang memutar dengan kaki kanan menopang tubuh untuk menjaga keseimbangan.

Sejalan dengan hasil penelitian (Yu et al. 2018) yang mengukur gerakan biomekanika teknik topspin bahwa torsi rotasi bahu saat melakukan teknik topspin memiliki hubungan yang sangat signifikan, gerakan rotasi ini berasal dari energi yang didapat melalui otot lengan. Transfer energi yang efisien dari tungkai bawah dan torsi sendi bahu sangat penting untuk menciptakan kecepatan pukulan yang tinggi. Selain itu, kontribusi rotasi tubuh bagian bawah juga memberikan kekuatan sehingga memberi dampak pada kekuatan pukulan. Lebih lanjut otot tungkai bagian bawah menjadi sumber energi yang mentransfer aktivasi optimal dari segmen tubuh bagian bawah ke otot bagian atas melalui gerakan berurutan dari rantai kinetik (Girard et al. 2010). Oleh karena itu, teknik permainan tenis meja memiliki kualitas tinggi tidak hanya membutuhkan koordinasi otot lengan yang lebih besar, tetapi juga membutuhkan dukungan dari otot tungkai bagian bawah untuk memberikan akurasi dan stabilitas selama kompetisi dan latihan (Yu et al. 2019).

\section{SIMPULAN}

Berdasarkan data analisis diatas ditemukan nilai rerata tekukan siku pada saat posisi siap sebesar $92,8^{0}$, kemudian pada saat posisi ayunan sebelum memukul bola dengan sudut tekukan siku $142,4^{0}$, selanjutnya sudut tekukan siku saat memukul bola sebesar 117,8 $8^{0}$, lebih lanjut didapatkan sudut tekukan siku sesudah memukul bola sebesar 73,4 $4^{0}$. Hasil rerata jarak siku dari titik pusat saat posisi siap $68,728 \mathrm{~cm}$, saat posisi ayunan sebelum memukul bola $23,532 \mathrm{~cm}$, untuk posisi saat memukul bola dengan jarak 50,88 cm, dan jarak siku ke pusat saat gerak lanjutan $150,768 \mathrm{~cm}$. Selanjtunya hasil analisis sudut kecondongan tubuh saat posisi siap $161,6^{0}$, saat mengayunkan tangan $152,6^{\circ}$, kemudian kecondongan tubuh saat memukul bola $150,6^{\circ}$, dan untuk gerak lanjutan dengan kecondongan tubuh $166^{\circ}$. Untuk hasil analisis tekukan kaki kanan saat posisi siap $149,8^{0}$, posisi megayunkantangan $125,4^{0}$, saatperkenaan bola $125,6^{0}$, dan saat melakukan gerak lanjutan 1442,60. Dilanjutkan hasil rerata analisis sudut tekukan kaki kiri saat posisi siap $151,2^{0}$, posisi mengayungkan tangan dengan tekukan kaki kiri $126,2^{0}$, pada saat perkenaan bola membentuk sudut $130,4^{0}$, serta diiringi dengan gerak lanjutan membentuk sudut kaki kiri $146^{\circ}$. Serta menganalisis hasil rerata jarak kaki saat melakukan pukulan topsin pada posisi siap $186 \mathrm{~cm}$, saat backswing jarak kaki 196,638 cm, dan saat perkenaan bola 198,81 $\mathrm{cm}$, serta diringi gerak lanjutan 195,886 cm. Dari gerakan yang dilakukan masing-masing atlet sesuai anatomi tubuh masing-masing serta mengikuti posisi saat perkenaan bola. Perlu diperhatikan terdapat beberapa faktor yang mempengaruhinya yaitu pergerakan tangan, tumpuan kaki, tumpuan badan untuk melakukan gerakan dan daya ledak yang maksimal.

\section{DAFTAR PUSTAKA}

Anon. n.d. "Most Popular Sports List."

Bańkosz, Ziemowit, and Sławomir Winiarski. 2016. "The Kinematics of Table Tennis Racquet: Differences between Topspin Strokes.” The Journal of Sports Medicine and Physical Fitness 57(3):202-13.

Bańkosz, Ziemowit, and Sławomir Winiarski. 2020. "Using Wearable Inertial Sensors to Estimate Kinematic Parameters and Variability in the Table Tennis Topspin Forehand Stroke.” Applied Bionics and Biomechanics 2020. doi: 10.1155/2020/8413948.

Bartlett, Roger, Jon Wheat, and Matthew Robins. 2007. "Is Movement Variability Important for Sports Biomechanists?” Sports Biomechanics 6(2):224-43. 
Chiwen, Shen, Zhang Tong, Gu Nan, Zhu Ling, and Wang Hao. 2019. "Comparison and Analysis of the Techniques and Tactics of Zhang Jike Using New Plastic Ball and Celluloid Ball in the Match." Proceedings Book of the 16th ITTF Sports Science Congress 113-17.

Girard, Olivier, Frank Eicher, Jean-Paul Micallef, and Grégoire Millet. 2010. "Plantar Pressures in the Tennis Serve." Journal of Sports Sciences 28(8):873-80.

Iino, Yoichi, and Takeji Kojima. 2016. "Mechanical Energy Generation and Transfer in the Racket Arm during Table Tennis Topspin Backhands.” Sports Biomechanics 15(2):180-97.

Irmawati, Dina Ade, Pandu Kresnapati, and Muh. Isna. 2020. “Analisis Biomekanika Keterampilan Gerak Topspin Tenis Meja Pada Klub Alaska Kota Pekalongan.” Journal of Sport Coaching and Physical Education 5(2):103-8. doi: 10.15294/jscpe.v5i2.37070.

Ismi, Dyah, Husnul Hadi, and Muh Isna Nurdin. 2020. “Analisis Gerakan Forehand Pada Tenis Meja." 1(1):25-31.

Kertamanah, Alex. 2015. Teknik Dan Taktik Permainan Tenis Meja. edited by Engkus Kuswandi. Bandung: PT Remaja Rosdakarya.

Nasrulloh, Ahmad. 2009. "Pengaruh latihan aerobik kombinasi dengan teknik terhadap kemampuan kardiorespirasi efek tekanan udara terhadap fisiologi tubuh atlet." MEDIKORA $0(1)$.

Nasrulloh, Ahmad, Yudik Prasetyo, Sigit Nugroho, Rina Yuniana, Kukuh Wahyudin Pratama, Aida Mustapha, and Syed Zulkarnain Syed Idrus. 2020. "Tricet Method to Increase the Hypertrophy Muscle.” Journal of Physics: Conference Series 1529(3):032006. doi: 10.1088/1742-6596/1529/3/032006.

Nikolić, Ivana, Gordana Furjan-Mandić, and Miran Kondrič. 2014. "The Relationship of Morphology and Motor Abilities to Specific Table Tennis Tasks in Youngsters." Collegium Antropologicum 38(1):241-45.

Padulo, Johnny, Fabio Pizzolato, Sergio Tosi Rodrigues, Gian Mario Migliaccio, Giuseppe Attene, Raffaele Curcio, and Alessandro M. Zagatto. 2016. "Task Complexity Reveals Expertise of Table Tennis Players." The Journal of Sports Medicine and Physical Fitness 56(1-2):149-56.

Pueo, Basilio. 2016. "High Speed Cameras for Motion Analysis in Sports Science." Journal of Human Sport and Exercise 11(1):53-73.

Pueo, Basilio, and Jose Manuel Jimenez-Olmedo. 2017. "Application of Motion Capture Technology for Sport Performance Analysis."

Saleh, Muhammad, and Widiyanto Widiyanto. 2019. "The Need Analysis of Pencak Silat Speed Kick Instrument Based Technology.” 330(Iceri 2018):302-6. doi: 10.2991/iceri18.2019.63. 
Sanders, Ross, Stelios Psycharakis, Carla McCabe, Roozbeh Naemi, Chris Connaboy, Li Shuping, Greig Scott, and Alan Spence. 2006. "Analysis of Swimming Technique: State of the Art; Applications and Implications." Portuguese Journal of Sports Sciences 6(2):20-24.

Santosa, T. 2016. "Pengembangan Alat Bantu Return Board Untuk Forehand Topspin Tenis Teja." Jurnal Pedagogik Olahraga 2(2):30-48.

Southgate, Dominic F. L., Joe A. I. Prinold, and Robert A. Weinert-Aplin. 2016. "Motion Analysis in Sport.” Pp. 3-30 in Sports Innovation, Technology and Research.

Sugiyono. 2019. Metode Penelitian Pendidikan (Kuantitatif, Kualitatif, Kombinasi, R\&D Dan Penelitian Pendidikan). Bandung: Alfabeta.

Sumaryanto, Sumaryanto. 2015. "Perspektif Filsafat Olahraga Dalam Mewujudkan Masyarakat Sehat." Medikora IX(1). doi: 10.21831/medikora.v0i1.4646.

Suwadji, Ade, S. B. 2014. "ANALISIS GERAK LEMPAR LEMBING (Studi Pada Atlet Atletik Cabor Lempar Lembing PASI Sidoarjo, Ditinjau Dari Aspek Biomekanika Dan Kinesiologi).” E-Journal Kesehatan Olahraga FIK UNESA 02 Nomor 0:73-83.

Yu, Changxiao, Shirui Shao, Julien S. Baker, Jan Awrejcewicz, and Yaodong Gu. 2019. “A Comparative Biomechanical Analysis of the Performance Level on Chasse Step in Table Tennis." International Journal of Sports Science and Coaching 14(3):372-82. doi: 10.1177/1747954119843651.

Yu, Changxiao, Shirui Shao, Julien S. Baker, and Yaodong Gu. 2018. "Comparing the Biomechanical Characteristics between Squat and Standing Serves in Female Table Tennis Athletes." PeerJ 6:e4760. 